J. Lake Sci. (湖泊科学) , 2013, 25(6): 809-817

http: //www.jlakes.org. E-mail : jlakes@niglas.ac.cn

(C) 2013 by Journal of Lake Sciences

\title{
天目湖沙河水库水质对流域开发与保护的响应”
}

\author{
朱广伟, 陈伟民, 李恒鹏,任 理, 顾钊, 赵林林, 高永霞, 贺再再, 张运林, 崔 扬 \\ ( 中国科学院南京地理与湖泊研究所湖泊与环境国家重点实验室,南京 210008)
}

\begin{abstract}
摘 要: 利用长期水质监测资料,对苏南地区天目湖沙河水库十多年来的开发与保护工作的水库水质影响情况进行了分 析. 结果发现: 大规模放养鳙鱼等不合理的渔业开发对水库硅藻、蓝藻等浮游植物异常增殖有较大的促进作用; 在营养盐 处于中富营养水平下,利用不同食性鱼类的组合调控,能够较快地抑制浮游植物的异常增殖,但当浮游植物生物量下降 到一定程度以后,其控制能力下降,营养盐和气候因子的影响变得更为重要; 流域的旅游开发和农业开发都对水库营养 盐、透明度等水质指标产生较大影响,特别是坡地大规模茶叶种植等农业开发对水库氮的影响十分明显; 春季少雨等气 候变化因子对水库氮等营养盐浓度影响较大,但影响是短时段的. 研究表明,合理调控水库渔业养殖,控制流域农业、旅 游等开发活动强度, 减少农业化肥施用量, 恢复和扩大湿地等流域营养盐削减途径, 是沙河水库水质保护的关键, 也对同 类水库水质保护具有示范价值.
\end{abstract}

关键词: 天目湖;沙河水库;富营养化;生物操纵;氮磷比;气候变化

\section{Response of water quality to the catchment development and protection in Tianmuhu Reservoir, China}

ZHU Guangwei, CHEN Weimin, LI Hengpeng, REN Li, GU Zhao, ZHAO Linlin, GAO Yongxia, HE Ranran, ZHANG Yunlin \& CUI Yang

( State Key Laboratory of Lake Science and Environment, Nanjing Institute of Geography and Limnology, Chinese Academy of Sciences, Nanjing 210008 , P. R. China)

\begin{abstract}
Based on the 9-year monthly monitoring data, the response of water quality to the economic development activities and the protection countermeasures in catchment and water body of Tianmuhu Reservoir, a meso-eutrophic reservoir with an area of $12 \mathrm{~km}^{2}$ located in southeastern of China, was studied. The result showed that the high-density big-head carp (Hypophthalmichthys nobilis) cultivation benefited the algal bloom in the growth season of phytoplankton. Fishery adjustment, with decrease the bighead carp biomass and increase the silver carp (Hypophthalmichthys molitrix) to big-head carp ratio, significantly decreased the peak value of summer phytoplankton biomass. While when the biomass decreased to relative low value, such as $15 \mathrm{mg} / \mathrm{L}$, the control ability of fishery to phytoplankton became weak. The influence of nutrient condition and climate factor became more important to the growth of phytoplankton. Agricultural and tourism development dramatically enhanced the nutrients runoff to the reservoir, especially the tea-farming in the steep slopes strongly increase the spring nitrogen concentration in the reservoir. Low rainfall could significantly decrease the nitrogen concentration in the water on the seasonal scale. This study suggests fishery adjustment, strictly controlling agriculture and tourism development, decreasing the fertilizer application, and expanding the wetland buffer area in the catchment, are the fundamental countermeasures for the water protection in the reservoirs located at southern China like Tianmuhu Reservoir.
\end{abstract}

Keywords: Tianmuhu Reservoir; Shahe Reservoir; eutrophication; biomanipulation; nitrogen phosphorus ratio; climate change

水库在我国水资源供给和水生态环境中起着至关重要的作用 ${ }^{[1]}$. 水库不但承担着渔业养殖、旅游、防 洪、农业灌溉、小气候调节等功能,还越来越多地承担了饮用水水源地的功能. 随着水库饮用水水源地功能

* 国家自然科学基金项目 (51279194)、中国科学院南京地理与湖泊研究所 “一三五”重点布局项目 ( NIGLAS2012135002) 和溧阳市沙河水库管理处科研项目联合资助. 2013-03-04 收稿;2013-04-26 收修改稿. 朱广伟, 男,1972 年生, 博士, 研究员; E-mail: gwzhu@ niglas. ac. cn. 
的不断强化, 过去传统的渔业养殖功能逐步下降 ${ }^{[2]}$, 解决水质问题逐步成为水库管理中的首要任务 ${ }^{[3]}$.

天目湖沙河水库建于 1959 年, 水面面积 $12 \mathrm{~km}^{2}$, 平均水深 $7 \mathrm{~m}$, 最大水深 $14 \mathrm{~m}$, 总库容 $1.09 \times 10^{8} \mathrm{~m}^{3}$, 属 大 II 型水库, 是苏南丘陵山区最大的水库之一 ${ }^{[4]}$. 沙河水库目前的主要功能是市政供水和旅游, 是溧阳市 60 万人口的饮用水水源地,也是国家 $\mathrm{AAAA}$ 级旅游区, 年游客人数超过 400 万人 ${ }^{[5]}$.

沙河水库的发展历程及当前面临的水环境问题在我国东南沿海地区十分普遍. 自 1962 年建成以来,先 后经历了渔业开发、旅游开发、有机农业开发等几个开发阶段, 水质不断受到威胁. 面临的最主要问题是透 明度下降、饮用水供水品质下降、藻类异常增殖等富营养化问题 ${ }^{[6-8]}$. 因此, 水质保护与富营养化防控也是沙 河水库水质管理的重中之重, 一直得到溧阳市政府的高度重视. 自 2006 年专门设立溧阳市天目湖水源地生 态环境保护工作领导小组办公室以来, 更是推进实施了流域生态保护规划制定、保护区范围红线划定、流域 湿地构建、入湖河流整治、农村生活污水整治、水库清淤、渔业调控等一系列保护工程措施, 对沙河水库的水 质产生了影响,缓解了流域大规模农业和旅游开发对水库水质的不利影响.

然而, 沙河水库的保护与开发始终并存, 开发与保护的内容不断变化, 水库的保护跟不上流域开发, 水 体和生态脆弱性逐渐显露, 致使其水质很不稳定. 这种现象在我国东南地区的水库管理上很具代表性. 为进 一步认识流域开发与保护对水库水质的影响, 本文利用沙河水库多年的水质监测资料, 分析了沙河水库富 营养化相关指标的变化规律, 结合流域开发与保护工程因素分析, 探讨人类活动强烈干扰下的水库水质保 护效果及水质影响因素, 为我国东南丘陵山区水库的水质保护及水资源安全供给提供科学依据.

\section{1 材料与方法}

\section{1 样点布设与样品采集}

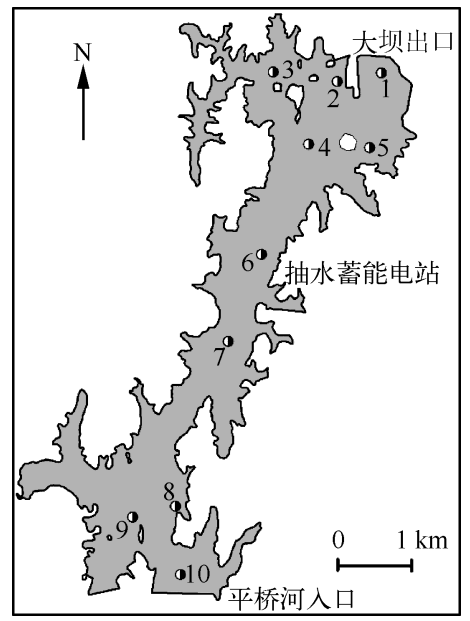

图 1 沙河水库监测点布设

Fig. 1 Sampling sites in Shahe Reservoir
分别于 2001 年 6 月- 2002 年 5 月、2006 年 1- 12 月、2008 年 5 月-2012 年 12 月, 逐月对沙河水库中 $8 \sim 10$ 个水质监测点 (图 1 ) 进行监测, 其中 2008 年 5 月-2009 年 12 月加密监测, 监测方法 见文献 $[6,8-10]$. 为了便于统一, 水质监测数据均选取表层 $0.5 \sim$ $1.0 \mathrm{~m}$ 的水样分析结果. 透明度 $(\mathrm{SD})$ 的测定采用赛氏黑白盘.

2011-2012 年水库降雨数据来自沙河水库 9 号监测点西岸的 山顶气象站. 该气象站提供按日统计的降雨量数据. 部分 2010 年 的降雨数据则来自沙河水库管理处水文站逐日监测资料.

\section{2 水样分析方法}

浮游植物鉴定时, 取 $1 \mathrm{~L}$ 水用鲁哥试剂固定后, 使用 Olympus $\mathrm{CH}$ 生物光学显微镜镜检浮游植物样品. 并结合经验公式估算浮游 植物的生物量 $(\mathrm{BioM}, \mathrm{mg} / \mathrm{L})$.

水样中总氮 $(\mathrm{TN})$ 采用过硫酸钾消解, 紫外分光光度法测定; 总磷 $(\mathrm{TP})$ 采用过硫酸钾消解, 钿锑抗比色法测定 ${ }^{[11]}$; 溶解性总氮 (DTN)、溶解性总磷 (DTP) 的测定: 水样过 $0.45 \mu \mathrm{m}$ 孔径 GF/F 玻 璃纤维滤膜后, 测定其 TN 、TP 含量; 硝态氮则采用 Skalar 流动分析 法测定; 叶绿素 $\mathrm{a}(\mathrm{Chl} . \mathrm{a})$ 采用热乙醇提取, 分光光度法测定 ${ }^{[12]}$; 悬浮颗粒物 (SS) 为 GF/F 滤膜过滤后重量法测 定, 将滤膜上的颗粒物 $105^{\circ} \mathrm{C}$ 下烘干后用马弗炉 $550^{\circ} \mathrm{C}$ 灼烧 $2 \mathrm{~h}$, 估算悬浮物的有机质比例 ( LOI $)^{[13]}$; 高锰酸盐 指数 $\left(\mathrm{COD}_{\mathrm{Mn}}\right)$ 采用氧化还原滴定法测定 ${ }^{[12]}$.

\section{3 统计方法}

数据统计与分析采用 Excel 2010 完成.

\section{2 结果与分析}

\section{1 水体总氮与溶解性总氮}

沙河水库水体总氮呈现明显的季节性变化 (图 2a), 特别是 2009 年以来, 春季的峰值变得非常明显. 

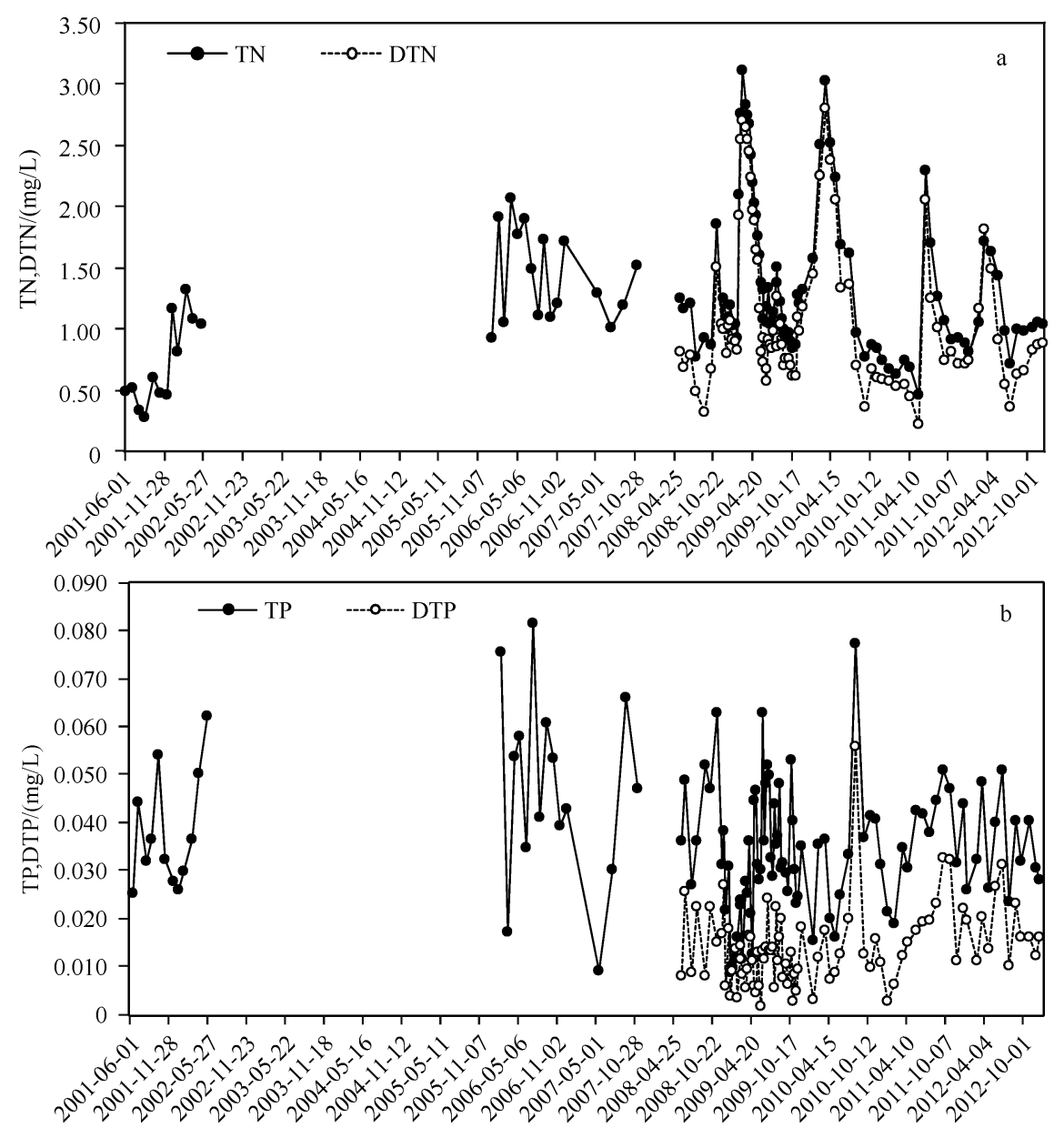

图 2 沙河水库水体总氮、溶解性总氮 ( a ) 和总磷、溶解性总磷 (b) 月均浓度

Fig. 2 Average total nitrogen and dissolved total nitrogen concentrations(a), tatal phosphorus and dissolved total phosphorus(b) in Shahe Reservoir

2001-2002 年, 水体总氮年平均含量为 $0.71 \mathrm{mg} / \mathrm{L}$, 最大值为 $1.31 \mathrm{mg} / \mathrm{L}$, 最小值为 $0.27 \mathrm{mg} / \mathrm{L}$, 相差 $1.04 \mathrm{mg} / \mathrm{L} .2006-2007$ 年水体总氮平均值为 $1.43 \mathrm{mg} / \mathrm{L}$, 其中最大值为 $2.06 \mathrm{mg} / \mathrm{L}$, 最小值为 $0.91 \mathrm{mg} / \mathrm{L}$, 相 差 $1.15 \mathrm{mg} / \mathrm{L} .2009$ 年总氮平均值为 $1.49 \mathrm{mg} / \mathrm{L}$, 其中最大值为 $3.09 \mathrm{mg} / \mathrm{L}$, 最小值为 $0.84 \mathrm{mg} / \mathrm{L}$, 相差 $2.25 \mathrm{mg} / \mathrm{L}$. 之后尽管年变幅开始降低,但仍处于较大的变幅状态. 2010-2012 年的平均值分别为 $1.61 、 1.01$ 和 $1.11 \mathrm{mg} / \mathrm{L}$, 其中 2012 年最大值为 $1.70 \mathrm{mg} / \mathrm{L}$, 最小值为 $0.71 \mathrm{mg} / \mathrm{L}$.

水库总氮年变幅的增大反映出外源控制因素单一化越来越严重. 结合流域保护与开发过程看,与 2009 年以来大规模的茶园开发等农业开发活动加强有关. 2009 年沙河流域茶园面积超过流域总面积的 $8 \%$,且 呈现不断增加的趋势.

从总氮的年平均值看, 沙河水库水质每 4 年下降一个等级. 2002- 2006 年, 总氮浓度有一个快速升高的 过程,从 III类水水平快速增高到IV 类水水平. 从 2006-2010 年则又有一个快速升高的过程,年平均值从 IV 类 水水平又增高到 $V$ 类水水平. 从 2010 年开始, 总氮含量才开始下降, 但直到 2012 年, 仍明显高于 2002 年的 水平, 总体属于 $I V$ 类水水平.

沙河水库水体中的氮主要以溶解态形式存在. 2008 年 5 月至 2012 年 12 月共计 85 次调查中,水体总氮 平均值为 $1.34 \mathrm{mg} / \mathrm{L}$, 溶解性总氮平均值为 $1.10 \mathrm{mg} / \mathrm{L}$, 约占总氮的 $82 \%$, 其中硝态氮的比例很高. 同期硝态 
氮平均值为 $0.69 \mathrm{mg} / \mathrm{L}$, 占溶解性总氮的 $63 \%$, 这与 $2008-2009$ 年的调查结果一致 ${ }^{[9]}$.

\section{2 水体总磷与溶解性总磷}

与氮的情况不同, 沙河水库水体总磷的含量年际变化较小, 月间的变化却很大 (图 2b). 2001-2002 年, 水库总磷平均值为 $0.038 \mathrm{mg} / \mathrm{L}$, 其中最大值为 $0.062 \mathrm{mg} / \mathrm{L}$, 总体呈 III 类水水平. $2006-2007$ 年总磷平均值 为 $0.047 \mathrm{mg} / \mathrm{L}$, 其中最大值为 $0.082 \mathrm{mg} / \mathrm{L}$, 总体仍呈 III 类水水平, 但比 $2001-2002$ 年增高了 $24 \% .2008-$ 2012 年总磷的年平均值分别为 $0.040 、 0.032 、 0.034 、 0.037$ 和 $0.035 \mathrm{mg} / \mathrm{L}$, 基本比较稳定, 且总体上明显低 于 2006-2007 年的状况,也低于 2001-2002 年期间的状况. 年际间的变幅明显小于月间变幅. 2006 年总磷 属于调查期间的最高值. 结合流域的开发过程分析, 这与 2003-2006 年旅游区临湖面大规模的开发活动以 及流域农业综合开发活动有关.

与氮不同, 沙河水库中的磷主要以颗粒态形式存在. 2008 年 5 月- 2012 年 12 月, 水体总磷平均值为 $0.034 \mathrm{mg} / \mathrm{L}$, 同期溶解性总磷平均值为 $0.014 \mathrm{mg} / \mathrm{L}$. 颗粒态磷平均占总磷的 $59 \%$. 这与 $2008-2009$ 年加密 监测的数据一致 ${ }^{[9]}$. 与总磷相比, 溶解性总磷的含量月变化和年变化都更小.

\section{3 氮磷比}

水体氮磷比的高低对于浮游植物群落结构有较大的影响 ${ }^{[14]}$. 特别是对于颗粒物较少、透明度较高的深 水水体. 当氮磷比低于 30 时, 氮对蓝藻生长的限制作用可能就会显现 ${ }^{[15]}$.

沙河水库水体氮磷比变化较大 (图 3). 2001-2002 年氮磷比年平均值为 20 , 只有 1 月和 3 月氮磷比超 过 29 , 其余月份均低于 29 , 这说明当时水库水体藻类的生长会受到氮供给的限制. 2006 年氮磷比平均值为 34,2007 年平均值为 57,2009 年更是增高到 62,2010 年平均值为 61 . 氮磷比显著高于 29 , 说明这一阶段水体 藻类生物量可能基本不受氮供给的控制, 营养盐方面主要受磷含量的影响. 2011 年氮磷比年平均为 28 , 重新 回到氮、磷同时控制的情况. 2012 年则又有所增高, 年平均值为 33, 其中 6-9 月的水华期有 2 个月氮磷比低 于 29 , 说明藻类异常增殖过程仍会受到氮供给的影响.

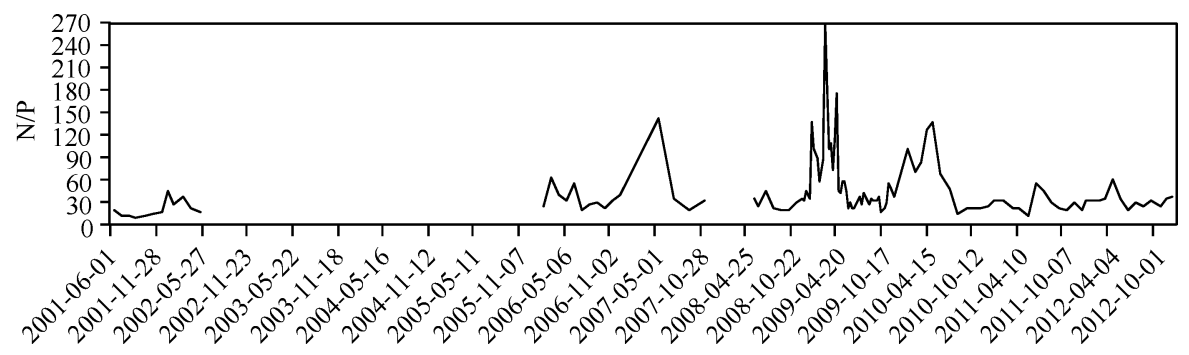

图 3 沙河水库水体氮磷比变化

Fig. 3 Changes of the ratio of total nitrogen and total phosphorus in Shahe Reservoir

\section{4 高锰酸盐指数与悬浮颗粒物}

总体上沙河水库水体 $\mathrm{COD}_{\mathrm{Mn}}$ 的变化不大, 多年平均值为 $3.45 \mathrm{mg} / \mathrm{L}$, 属于 III 类水水平. 其中 $2001-2002$ 年平均值为 $3.47 \mathrm{mg} / \mathrm{L}, 2006-2012$ 年逐年平均值分别为 $3.67 、 4.25 、 4.08 、 3.56 、 3.07 、 2.87$ 和 $3.06 \mathrm{mg} / \mathrm{L}$, 均属于 III类水水平. 其中 2006-2008 年有个高峰值, 与农业开发过程关系更为密切 (图 4a).

沙河水库水体 $\mathrm{COD}_{\mathrm{Mn}}$ 与有机态悬浮颗粒物关系密切, 如 2008 年 5 月至 2012 年 12 月间, 通过烧失量估 算的有机悬浮物含量平均值为 $4.64 \mathrm{mg} / \mathrm{L}$, 其月变化与水体 $\mathrm{COD}_{\mathrm{Mn}}$ 的变化相似 (图 $4 \mathrm{a}$ ), 相关系数达 0.94 $(n=81)$, 说明有机颗粒物是水体中 $\mathrm{COD}_{\mathrm{Mn}}$ 的主要贡献者.

从年变化看, 悬浮物浓度总体呈先升高后降低的趋势, 峰值出现在 2008-2009 年. 2006-2012 年逐年 $\mathrm{SS}$ 平均值分别为 $6.80 、 9.82 、 11.00 、 10.83 、 10.15 、 8.08$ 和 $6.76 \mathrm{mg} / \mathrm{L}$ (图 4a). 在 $2008-2009$ 年, $\mathrm{SS}$ 呈现较 高的月变化, 主要是受降雨过程影响, 反映出期间流域植被破坏较严重, 水土流失程度相对较高, 这可能与 期间的农业开发活动有关.

水体透明度的情况基本上与 $\mathrm{SS}$ 呈反比. 2001-2002 年透明度平均值为 $145 \mathrm{~cm}, 2006-2012$ 年逐年平均 值分别为 $116 、 95 、 91 、 99 、 106 、 111$ 和 $120 \mathrm{~cm}$ (图 4a), 呈现单峰下降再升高的趋势, 其中 2007-2009 年透明 
度最低,也可能与当时的农业及旅游开发活动有关.

\section{5 叶绿素与浮游植物生物量}

从浮游植物生物量看, 2006 年出现一个极高的峰值 (图 4b). 2006 年 5 月水库浮游植物生物量平均值达 $127.142 \mathrm{mg} / \mathrm{L}$, 而 2002 年 5 月, 全库平均浮游植物生物量仅为 $22.694 \mathrm{mg} / \mathrm{L}, 4$ 年增高了近 6 倍. 事实上 2004-2005年浮游植物异常增殖的水质问题已经出现, 浮游植物生物量过高, 影响到水体透明度, 到 2006 年时该问题显得最为突出.
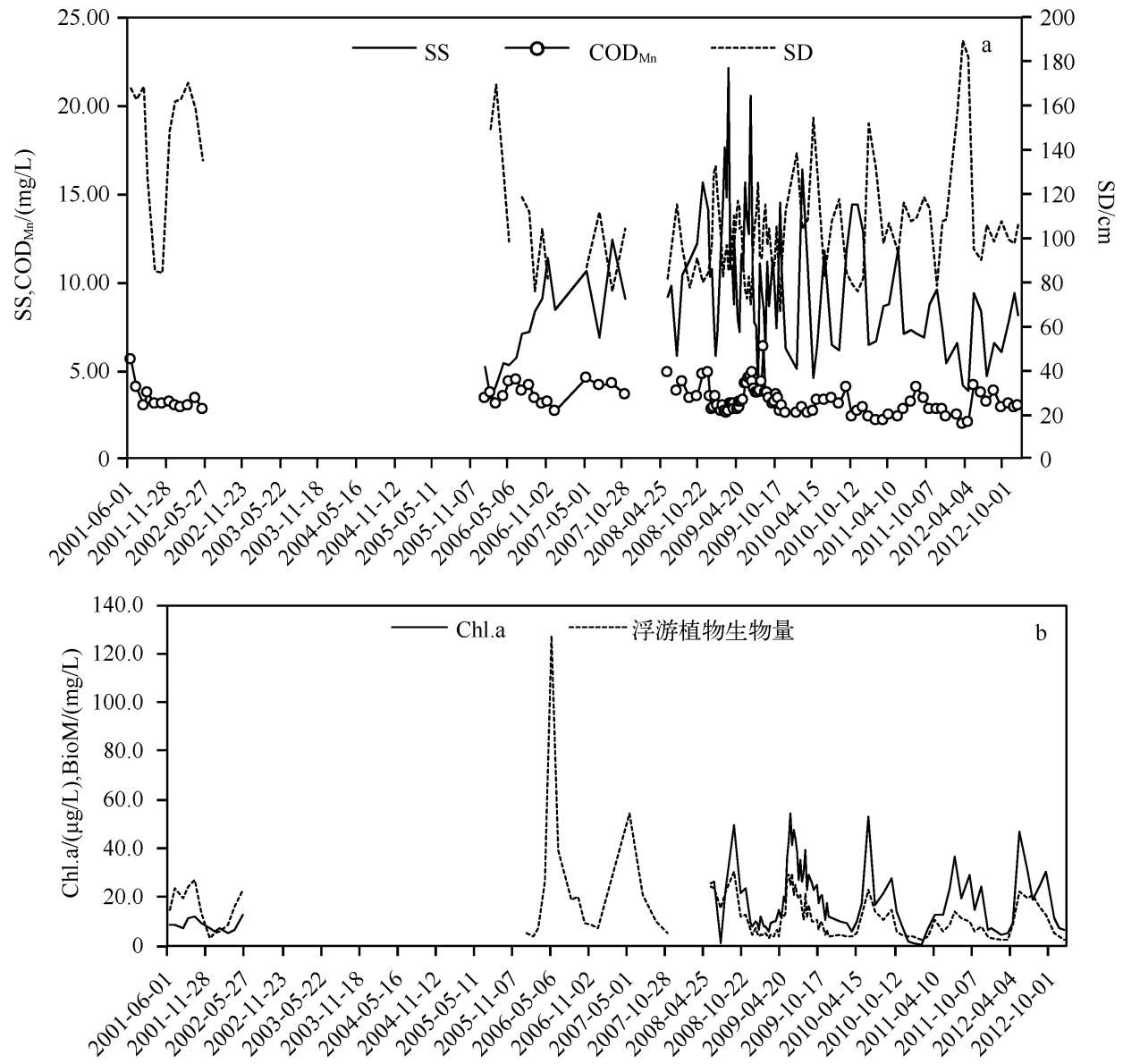

图 4 沙河水库水体 $\mathrm{SS} 、 \mathrm{COD}_{\mathrm{Mn}} 、 \mathrm{SD}(\mathrm{a})$ 和叶绿素 $\mathrm{a}$ 含量、浮游植物生物量 $(\mathrm{b})$ 变化

Fig. 4 Changes of $\mathrm{SS}, \mathrm{COD}_{\mathrm{Mn}}, \mathrm{SD}(\mathrm{a})$ and the chlorophyll-a, phytoplankton biomass concentration(b) in Shahe Reservoir

2006 年以后, 浮游植物生物量大致呈现快速下降的趋势, 2006-2012 年的逐年平均值分别为 25.225 、 $22.560 、 15.893 、 8.875 、 7.255$ 和 $9.885 \mathrm{mg} / \mathrm{L}$; 而 $2001-2002$ 年的 12 个月平均值为 $15.364 \mathrm{mg} / \mathrm{L}$. 这说明单 从浮游植物生物量的角度看, 2010 年以来已经低于 2001 年了.

结合沙河水库及流域的开发与保护历程,2006 年前后的浮游植物生物量急剧增加除了与流域开发活动 加剧有关外, 主要受鲜鱼的过度养殖影响. 沙河水库自 1959 年建库初期就放养鱼类, 1960-1969 年的平均 年产量为 $8.50 \mathrm{t}, 1970-1979$ 年的平均年产量为 $9.81 \mathrm{t}, 1980-1988$ 年的平均年产量为 $18.74 \mathrm{t}^{[4]}$, 已经达到 较高的产量, 此后至 1999 年产量基本稳定. 然而,1997 年以后,因天目湖砂锅鱼头产品开发及旅游市场的大 力开发, 沙河水库鳙鱼养殖开始混乱, 大量投放鳙鱼, 捕捞也采用全年捕捞,鲢鱼的放养基本停滞. 直至 2006 年重新调整渔业管理,鲢、鳙鱼的放养比例控制在 8:2 左右, 同时降低总放养量, 对水体浮游植物生物量起到 
了控制作用. 但从 2008 年以后, 渔业调控对藻类的控制能力似乎已经很有限了.

叶绿素 a 含量的变化情况与浮游植物生物量的变化非常吻合. 利用 2008 年 5 月至 2012 年 12 月 85 次 调查数据进行线性拟合, $\rho(\mathrm{BioM})=0.501 \rho(\mathrm{Chl} . \mathrm{a})+1.263$, 相关性达 0.86 , 这说明沙河水库的叶绿素 a 含 量能够正确反映浮游植物生物量的状况.

\section{6 富营养化指数}

根据 Carlson 营养状态指数及我国湖泊富营养化指数 ${ }^{[16-17]}$, 利用 Chl. a 、TP、TN、SD、COD ${ }_{\mathrm{Mn}}$ 等 5 个参数计 算了沙河水库的营养状态指数 (图 5). 其中 TSI ( TP) 计算采用 Carlson 的公式 ${ }^{[16]}$, 其余指标采用王明翠等的 公式 ${ }^{[17]}$. 结果表明, 沙河水库水体营养状态综合指数 $T S I$ 平均值为 50 , 月最大值为 58 , 最小值为 36 , 属于中 富营养水平. 其中 $2001-2002$ 年 $T S I$ 平均值为 46,2006-2012 年的年均值则分别为 $51 、 51 、 52 、 51 、 50 、 47$ 、 48. $T S I(\mathrm{Chl} . \mathrm{a}) 、 T S I(\mathrm{TP}) 、 T S I(\mathrm{TN}) 、 T S I(\mathrm{SD})$ 和 $T S I\left(\mathrm{COD}_{\mathrm{Mn}}\right)$ 的多年平均值分别为 $53 、 55 、 57 、 50$ 和 33 , 总氮、 总磷、浮游植物生物量是主要贡献因子; 其中 2012 年的 $T S I(T N) 、 T S I(T P)$ 和 $T S I($ Chl. a) 分别为 $56 、 55$ 和 52 (图 5), 氮和磷是主要贡献因子.

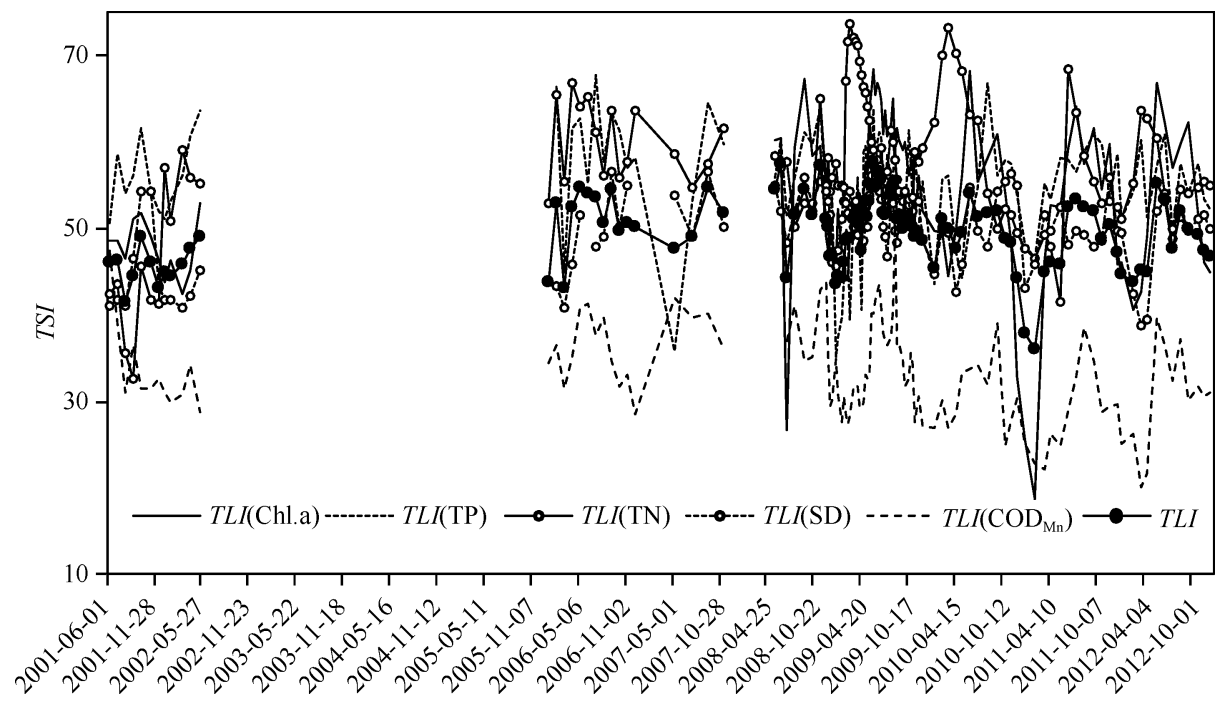

图 5 沙河水库富营养化指数变化

Fig. 5 Change of the trophic state index (TSI) in Shahe Reservoir

\section{3 讨论}

\section{1 渔业过度养殖和比例失调对水库水质影响很大}

沙河水库的水质问题从 2000 年左右开始出现, 主要问题是夏季透明度差, 春末夏初针杆藻等硅藻疯 长, 夏季席藻等蓝藻疯长, 大大影响水库饮用水的原水供给及旅游功能. 2005 年甚至出现自来水二甲基异茨 醇和土臭素超标问题,引起社会和政府的高度重视.

水质快速恶化的首要因素是 1997-2005 年的渔业过度养殖. 渔业生产对水库浮游植物影响甚大 ${ }^{[18-19]}$. 天目湖旅游开发始于 1992 年 4 月, 1994 年 7 月被江苏省人民政府批准为省级旅游度假区, 1997 年开发出 “沙河鱼头”招牌菜,2001 年 1 月被国家旅游局评为首批 AAAA 级旅游区, 游客大量增加,达到 400 万人/年. 使得鳙鱼成为沙河水库养殖的主要经济鱼种.

早期的沙河水库渔业养殖的主要目标是追求总产量, 鲢鱼与鳙鱼的比例一直相差不大. 但 1997 年以后 由于鳙鱼价格大大超过鲢鱼, 为了追求高利润, 放养比例严重失调, 鳙鱼的放养规模增大, 提高到 $1.75 \sim$ $2.50 \mathrm{~kg}$ 尾, 1997-2001 年鳙鱼逐年放养量为 $54.9 \% 、 70.4 \% 、 72.4 \% 、 85.1 \%$ 和 $94.4 \%$, 导致天目湖自然生 物群落结构的破坏, 食物链关系脱节, 浮游生物小型化, 野杂鱼种群严重衰退, 甚至出现鳙鱼生长率等于零 
的年份 (2000 年). 伴随其后的是水质的快速恶化,特别是夏季浮游植物生物量的快速增加.

2006 年开始调整沙河水库的渔业养殖结构与规模,将鲢鱼和鳙鱼的投放比例提高到 9:1, 并降低投放 量, 通过捕捞降低水库鲢鱼和鳙鱼的总库存量. 同时投放以有机碎屑为主要食物的野杂鱼,对浮游植物生物 量的控制起到了很好的效果. 浮游植物生物量逐年下降,2008 年以后大部分月份的生物量都控制在 $15 \mathrm{mg} / \mathrm{L}$ 以下 (图 4b). 但其后浮游植物生物量基本维持在年均 $10 \mathrm{mg} / \mathrm{L}$ 左右, 下降幅度有限. 说明渔业调控的下行效 应能力已经接近上限, 而营养盐供给的上行效应对浮游植物生物量的影响越来越明显.

\section{2 农业与土地开发对沙河水库水质影响甚大}

21 世纪沙河水库的流域土地开发分两个阶段:2003-2006 年的临湖面宾馆、饭店、娱乐场地等旅游设 施、房地产开发、局部农业开发为第一阶段; 2007-2010 年流域大面积茶叶种植等特色农业开发为第二阶 段. 其中第二阶段开发的面积和化肥施用量等影响大于前者,特别是对水库氮的影响最为显著.农业开发与 水库氮的浓度增加过程十分吻合,其影响程度超过了前期的旅游开发. 而且农业开发时水库水质的影响呈 现明显的季节特征: 春季茶叶施肥期, 水库氮浓度大大增加, 一场春雨能将水库总氮浓度增加 1 倍 (图 2a). 另外, 流域农业开发期间对土地扰动强度较大, 水土流失强度加大, 对水库悬浮颗粒物等的影响也比较 明显.

2011 年以来, 在及时开展了流域生态保护规划工作以后, 茶园开发的速度得到了很大控制. 茶园开发的 区域得到限制,在坡度大的水源涵养林区禁止茶园等的开发. 同时,要求在茶园周边构建植被缓冲带,并尝 试使用 “反硝化沟” 等脱氮技术去除茶园等地下水中的氮. 另外, 在河流人库区, 构建大面积河口湿地, 以增 加氮和磷的去除, 初步控制了水库氮的增加.

然而, 应对农业开发的保护措施仍在摸索当中, 土地开发带来的营养盐人湖通量的增量与保护带来的 减量之间仍在博亦. 控制开发面积、规模,降低农业生产中的化肥投放,是水库水质进一步提高的关键所在. 在农业活动控制的基础上,加强流域湿地建设对营养盐的人库通量也有较大的影响. 李兆富等的研究也表 明,沙河水库流域湿地面积、位置、密度、生态类型等对氮、磷输出都具有重要的影响 ${ }^{[20]}$.

\section{3 降低营养盐是沙河水库水质进一步提高的关键}

2012 年, 沙河水库的总氮浓度平均值为 $1.11 \mathrm{mg} / \mathrm{L}$, 总磷浓度平均值为 $0.035 \mathrm{mg} / \mathrm{L}$, 叶绿素 a 平均含量 为 $16.9 \mu \mathrm{g} / \mathrm{L}$, 在 5-9 月的藻类快速生长期, 叶绿素 $\mathrm{a}$ 的平均含量更是高达 $30.4 \mu \mathrm{g} / \mathrm{L}$, 较早两年水质出现了 倒退现象. 这与氮和磷浓度正处于富营养化状态有很大关系. 2012 年的 TSI (TN)、TSI (TP) 和 TSI (Chl. a) 分 别为 $56 、 55$ 和 52 . 营养盐对藻类的生长而言还是比较充分的. 在这种高营养盐浓度的环境下, 藻类的异常增 殖更多地受气象条件的影响.

2008 年 5 月以来沙河水库总氮的月变化过程与浮游植物生物量之间具有较大的相似性. 不同年份的浮 游植物生物量峰值高低与总氮的峰值具有较多的一致性. 2011 年浮游植物生物量出现最低值, 与 2011 年 6 月前连续 10 个月水库总氮持续低于 $1.0 \mathrm{mg} / \mathrm{L}$, 特别是不存在春季峰值有很大的关系 (图 $6 \mathrm{a}$ ).

磷的变化曲线与夏季浮游植物生物量之间的变化过程也很接近. 尽管氮、磷并不是影响浮游植物生物 量的唯一因素,但营养盐浓度高低对沙河水库浮游植物的异常增殖具有重要的影响.

2011 年上半年总氮浓度持续较低的原因并非是流域污染控制的影响, 而是春季干旱的结果. 春季干旱 缺雨是水库总氮较低的关键 (图 6b). 2010 年 8 月至 2011 年 5 月的 10 个月中, 总降雨量为 $450 \mathrm{~mm}$, 月平均 降雨量为 $45 \mathrm{~mm}$, 基本没有形成有效的地表径流. 降雨过程与总磷含量关系也比较密切: 大的降雨峰值之后 往往伴随一个总磷浓度峰值.

毫无疑问, 水文过程影响水库营养盐浓度 ${ }^{[21]}$. 近年来, 异常气候出现的频率越来越高, 这方面的报道也 越来越多 ${ }^{[22-24]}$. 然而, 异常气候事件是无法预料和控制的. 而对于水库管理者而言,所能做的仍是控制流域 营养盐的输出风险, 这样才能在极端气候事件越来越多的未来,将水库的水质保持在较好的状态.

\section{4 结论}

天目湖沙河水库既承担着城市供水功能, 又承担着旅游功能, 还兼具渔业养殖、防洪、农业灌溉、抽水蓄 能电站等功能,在长三角地区水库管理中具有较高的代表性. 沙河水库流域近十几年来的开发和保护工作 
对水库的水质产生了明显影响. 监测结果表明, 渔业养殖对水库浮游植物生物量具有较大的影响, 从追求渔 业产量、产值, 向服务于水质管理目标的思路转变, 是作为饮用水水源地水库管理必须高度重视的方面.
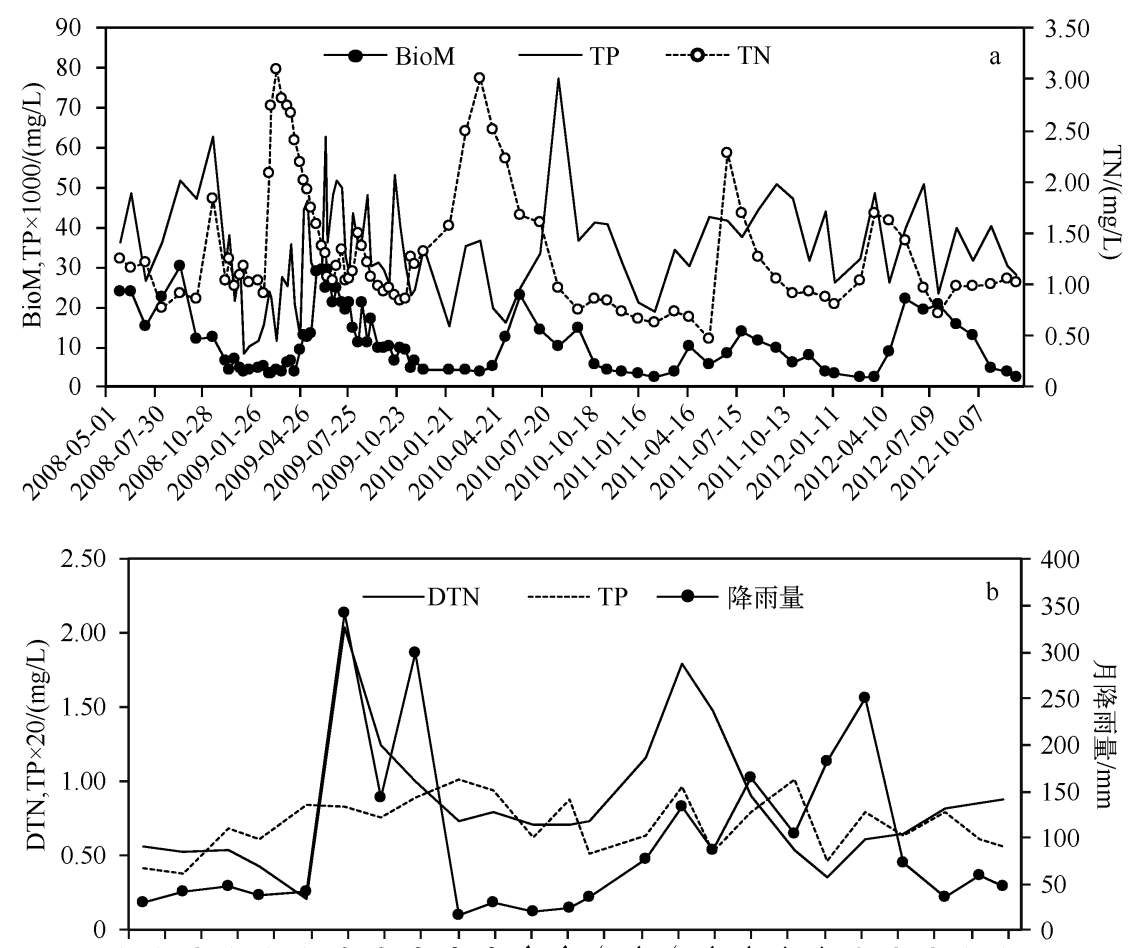

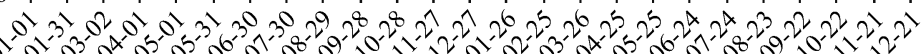

$0^{2}=0$

图 6 沙河水库水体营养盐与浮游植物生物量 (a)、氮磷浓度与降雨量之间 (b) 的关系

Fig. 6 Relationship between phytoplankton biomass and nutrient concentrations(a), nutrient concentrations and rainfall(b) in Shahe Reservoir

无论是旅游开发, 还是农业开发, 对水库的富营养化影响都较大, 特别是应该高度重视农业的无序开发 影响. 流域坡地是农业开发的重点、土地利用由林地流转为新开剭的茶田, 导致严重的水肥流失, 以及水库 营养盐浓度的增高. 沙河水库近两年水质有所改善的主要原因是管理思路与对策的转变. 包括制定详实的 流域生态保护规划, 提出严格保护区, 控制农业与旅游产业开发区的空间范围、比例、空间区域,并落实保护 和开发的协调方案.

气候的年际波动和极端气候事件可能都会明显影响当年的水库水质状况. 然而, 对于中富营养或者水 质更为清洁的水库, 严格控制水库营养盐浓度, 才是降低水质安全风险、确保水库不发生较为严重水质事件 的根本之策.

致谢: 溧阳市天目湖镇高荣平书记、溧阳市环境保护局天目湖分局周涛局长、沙河水库管理处周世平、高志 勤等协助完成了多年的水质监测及资料补充, 中国科学院南京地理与湖泊研究所的周万平研究员、董雅文 教授、罗潋葱研究员、陈开宁研究员、庄大栋副研究员、聂小飞博士生参与了生物样品鉴定、研究思路讨论、 鱼类状况调查、水质野外调查、气象资料收集等工作,在此一并表示感谢.

\section{5 参考文献}

[1] 韩博平. 中国水库生态学研究的回顾与展望. 湖泊科学, 2010,22(2) : 151-160.

[2] 万成炎, 吴晓辉, 朱爱民等. 江苏省大中型水库水质的理化特性及其渔业评价. 水利渔业, 2003,23(1):43-45,62. 
[ 3 ] 胡传林,万成炎,丁庆秋等. 我国水库渔业对水质的影响及其生态控制对策. 湖泊科学,2010,22(2):161-168.

[ 4 ] 江苏省溧阳市沙河水库管理处. 沙河水库志, 1991.

[ 5 ] 张运林,陈伟民,杨顶田等. 天目湖水环境现状及生态旅游可持续发展对策. 生态环境,2003,12(4) :405-408.

[ 6 ] 张运林,陈伟民,杨顶田等. 天目湖 2001-2002 年环境调查及富营养化评价. 长江流域资源与环境,2005,14(1)： 99-103.

[ 7 ] 吴建丰,陈泽民. 天目湖富营养化现状研究. 污染防治技术,2006,19(6):23-25.

[8] 高永霞,朱广伟,贺冉再等. 天目湖水质演变及富营养化状况研究. 环境科学, 2009,30(3):49-55.

[9] 朱广伟,赵林林,陈伟民等. 低水位运行对天目湖水库水质与生态的影响. 生态与农村环境学报, 2011,27 (4): 87-94.

[10] 贺冉冉,高永霞,王 芳等. 天目湖水体与沉积物中营养盐时空分布及成因. 农业环境科学学报, 2009,28(2): 353-360.

[11］国家环境保护总局《水和废水监测分析方法》编委会. 水和废水监测分析方法:第 4 版 (增补版). 北京: 中国环境 科学出版社,2009:223-226,243-245,255-257.

[12] 陈宇炜, 陈开宁, 胡耀辉. 浮游植物叶绿素 a 测定的” 热乙醇法” 及其测定误差的探讨. 湖泊科学, 2006, 18 (5): $550-552$.

[13] 朱广伟,秦伯强,高 光等. 灼烧对沉积物烧失量及铁、磷测定的影响. 分析试验室,2004,23(8):72-76.

[14] Vrede B, Ballantyne A, Mille-Lindblom C et al. Effects of N:P loading ratios on phytoplankton community composition, primary production and $\mathrm{N}$ fixation in a eutrophic lake. Freshwater Biology, 54(2) : 331-344.

[15] Havens KE, James RT, East TL et al. N:P ratios, light limitation, and cyanobacterial dominance in a subtropical lake impacted by non-point source nutrient pollution. Environmental Pollution, 2003,122 : 379-390.

[16] Carlson RE. A trophic state index for lakes. Limnology and Oceanography, 1977, 22 (2) : 361-369.

［17］王明翠,刘雪芹,张建辉. 湖泊富营养化评价方法及分级标准. 中国环境监测, 2002,18(5):47-49.

[18] Scharf W. biomanipulation as a useful water quality management tool in deep stratifying reservoirs. Hydrobiologia, 2007, $583: 21-42$.

[19] Scharf W. Development of the fish stock and its manageability in the deep, stratifying Wupper reservoirs. Limnologica, 2008, 38: 248-257.

[20］李兆富,刘红玉, 李恒鹏. 天目湖流域湿地对氮磷输出影响研究. 环境科学, 2012,33(11):3753-3759.

[21] 黄群芳,张运林,陈伟民等. 天目湖水文特征变化及其对上游湿地和湖泊生态环境的影响. 湿地科学, 2007,5(1): 51-56.

[22] Yamamoto T, Kohmatsu Y, Yuma M. Effects of summer drawdown on cyprinid fish larvae in Lake Biwa, Japan. Limnology, 2006, $7: 75-82$.

[23] Mac Donagh ME, Casco MA, Claps MC. Plankton relationships under small water level fluctuations in a subtropical reservoir. Aquatic Ecology, 2009, 43: 371-381.

[24] Vilhena LC, Hillmer I, Imberger J. The role of climate change in the occurrence of algal blooms: Lake Burragorang, Australia. Limnology and Oceanography, 2010, 55(3): 1188-1200. 